\title{
HUBUNGAN KEMANDIRIAN BELAJAR DAN PERHATIAN ORANG TUA DENGAN PRESTASI BELAJAR
}

\author{
Oleh \\ Rikani Astuti \& Djihad Hisyam \\ djihad_hisyam@uny.ac.id
}

\section{ABSTRAK}

Penelitian ini bertujuan untuk mengetahui hubungan kemandirian belajar dan perhatian orang tua dengan prestasi belajar. Penelitian ini merupakan penelitian ex post facto, desain penelitiannya adalah korelasi. Penelitian ini bersifat kuantitatif karena dimaksudkan untuk mengetahui hubungan kemandirian belajar dan perhatian orang tua dengan prestasi belajar. Hasil penelitian menunjukkan bahwa: (1) terdapat hubungan positif dan signifikan antara kemandirian belajar dengan prestasi belajar yang ditunjukkan dengan koefisien korelasi sebesar 0,492 ( $\left.r_{\mathrm{h}} 0,492>r_{\mathrm{t}} 0,279\right) ;(2)$ terdapat hubungan positif dan signifikan antara perhatian orang tua dengan prestasi yang ditunjukkan koefisien korelasi sebesar 0,737 $\left(r_{h} 0,737\right.$ $>r_{\mathrm{t}}$ 0,279); (3) terdapat hubungan positif dan signifikan antara kemandirian belajar dan perhatian orang tua secara bersama-sama dengan prestasi belajar yang ditunjukkan dengan koefisien korelasi ganda $(R)$ sebesar 0,742 dan koefisien determinasi $\left(R^{2}\right)$ sebesar 0,550 , nilai $F_{\text {hitung }}$ yang diperoleh sebesar 28,779 sedangkan $F_{\text {tabel }}$ sebesar $3,18\left(F_{h}>F_{t}\right)$.

\section{Kata kunci: kemandirian belajar, perhatian orang tua dan prestasi belajar.}

\section{Pendahuluan}

Kemajuan ilmu pengetahuan dan teknologi di era globalisasi telah mengakibatkan perubahan dan perkembangan masyarakat ke arah kehidupan yang semakin kompleks. Keadaan tersebut menuntut masyarakat untuk dapat mengimbangi perkembangan dengan penyediaan sumber daya manusia yang berkualitas dan kompetitif. Salah satu upaya untuk meningkatkan kualitas sumber daya manusia adalah melalui pendidikan.

Seiring dengan perkembangan jaman, pendidikan dihadapkan pada berbagai permasalahan. Salah satu permasalahan yang dihadapi adalah rendahnya mutu pendidikan di berbagai jenjang pendidikan (Sumber: $h t t p: / / p e r i n g k a t-p e n d i d i k a n-i n d o n e s i a-t u r u n . h t m l$, diunduh 7 Februari 2012). Hal tersebut tentu saja akan menghambat penyediaan sumber daya manusia yang berkualitas dan kompetitif, oleh karena itu pendidikan harus ditingkatkan melalui berbagai upaya.

Salah satu upaya untuk mengetahui mutu pendidikan, dapat diketahui melalui prestasi belajar. Siswa memiliki prestasi yang tinggi apabila dalam proses pembelajaran didukung oleh 
sarana dan prasarana yang memadai, perhatian baik dari pemerintah maupun lingkungan, dan kemauan dari diri siswa untuk belajar:

Dalam mencapai prestasi belajar yang diharapkan, sebagian siswa terkadang menghadapi permasalahan. Hal ini dibuktikan dengan nilai ulangan yang diperoleh siswa, baik ulangan harian maupun ulangan semester yang belum memenuhi kriteria ketuntasan minimum sehingga perlu mengikuti ulangan perbaikan/remedial. Siswa terkadang memiliki rasa keterpaksaan, malas, dan kurang berkembang sikap kemandirian belajar pada diri siswa dalam mencapai prestasi belajar. Hal inilah yang diduga menjadi penyebab kurangnya daya serap siswa dalam mencapai prestasi belajar.

Sekolah Menengah Kejuruan adalah sekolah yang mempersiapkan peserta didik untuk mampu mandiri dan mencapai masa depan yang baik tanpa bergantung orang lain. Masa depan akan dapat tercapai apabila siswa mampu mandiri, dan kemandirian siswa diawali dengan kemandirian belajar. Pada kenyataannya, masih banyak siswa yang belum mandiri dalam belajar, masih menggantungkan diri pada orang lain, tidak mengerjakan tugas, tidak pernah belajar apabila tidak disuruh, pada saat ulangan mencontek teman dan saat mengerjakan pekerjaan rumah.

Siswa harus memiliki kemandirian belajar agar materi yang diberikan oleh guru dapat dikembangkan sendiri. Siswa juga harus memiliki keyakinan bahwa guru bukan satu-satunya sumber pengetahuan. Sumber pengetahuan utama tersedia di perpustakaan, media cetak atau audio-visual lain termasuk internet.

Kemandirian belajar adalah hasil suatu proses dari pengalaman itu sendiri. Apabila proses belajar tidak memberi pengalaman bahwa belajar merupakan suatu kegiatan individual, maka perilaku mandiri dalam belajar akan tetap merupakan suatu impian. Kemandirian belajar membawa dampak positif bagi siswa. Siswa yang mampu berusaha sendiri menyelesaikan masalah belajar, maka tidak perlu meminta bantuan orang lain, tidak terpengaruh oleh informasi yang diterima baik secara lisan maupun tulisan. Siswa yang mandiri mampu bersaing dengan orang lain, dapat mengambil keputusan untuk tindakan yang akan dilakukan.

Faktor lain yang mempengaruhi prestasi belajar adalah faktor keluarga, orang tua mempunyai peran yang dominan dalam pendidikan anak. Orang tua yang mempunyai perhatian tinggi terhadap kegiatan belajar anak di rumah akan menyebabkan prestasi belajar yang tinggi, sebaliknya orang tua yang sama sekali tidak memperhatikan kegiatan belajar akan menyebabkan anak menjadi kurang bersemangat dalam belajar, akibatnya prestasi belajar kurang memuaskan.

Pada kenyataannya terdapat orang tua yang kurang memberikan perhatian pada anak, mereka selalu disibukkan oleh pekerjaan masing-masing, padahal usia-usia remaja dimana 
gejolak perasaan sering berubah-ubah memerlukan kasih sayang, perhatian, bimbingan yang lebih dari orang tua untuk mengarahkan belajar yang baik. Dapat pula dijumpai orang tua yang terlalu berlebihan dalam memberi perhatian kepada anak, mereka terlampau cemas dengan keadaan-keadaan yang dihadapi anak. Sikap otoriter sering dipertahankan dengan dalih untuk menanamkan disiplin pada anak. Akibatnya anak menunjukkan sikap pasif, menyerahkan segala sesuatu kepada orang tua dan akan kehilangan kesempatan untuk belajar maupun berusaha bagi diri sendiri.

Peran dan partisipasi orang tua masih tetap dibutuhkan baik dengan memberi bimbingan pada anak, pengawasan di luar jam sekolah maupun dalam bentuk kerjasama dengan sekolah. Orang tua seringkali menyerahkan tanggung jawab kepada sekolah dalam mendidik anak bahkan bersikap acuh terhadap keadaan anak, hal ini menunjukkan kurang kesadaran orang tua terhadap pendidikan khususnya pendidikan sekolah.

Berdasarkan hasil pra survey, keberhasilan belajar siswa pada umumnya diserahkan kepada lembaga sekolah karena orang tua belum sepenuhnya fokus dalam mengawasi perkembangan belajar anak. Orang tua beranggapan bahwa yang terpenting sudah membiayai sekolah tetapi kurang memberikan perhatian untuk belajar. Perhatian orang tua akan membuat prestasi belajar meningkat dan optimal karena perhatian orang tua kepada anak yang tinggi membuat anak merasa dihargai oleh orang tua dalam kegiatan belajar.

Dari latar belakang yang dikemukakan, dapat diidentifikasi beberapa masalah, diantaranya: 1) Kemandirian belajar siswa masih kurang, 2) Masih banyak siswa yang mencontek saat ulangan, tidak mengerjakan pekerjaan rumah dan masih menggantungkan diri pada orang lain, 3) Siswa berkeyakinan bahwa guru adalah satu-satunya sumber belajar, hal ini membuat siswa enggan untuk melakukan kegiatan belajar sendiri tanpa diarahkan oleh guru, 4) Kurangnya perhatian orang tua terhadap pendidikan siswa, 5) Orang tua beranggapan bahwa keberhasilan belajar siswa diserahkan sepenuhnya kepada lembaga sekolah, 6) Masih banyak orang tua siswa yang belum mempunyai kesadaran tinggi terhadap pentingnya pendidikan khususnya pendidikan sekolah, 7) Prestasi belajar siswa belum memenuhi nilai Kriteria Ketuntasan Minimal (KKM).

\section{Deskripsi Teori}

\section{Pengertian Prestasi Belajar}

Prestasi belajar merupakan penguasaan pengetahuan atau ketrampilan yang dikembangkan oleh mata pelajaran, lazimnya ditunjukkan dengan nilai tes atau angka nilai yang diberikan oleh guru (Kamus Umum Bahasa Indonesia, 2007: 895). Sedangkan Muhibbin Syah (2006: 141) menjelaskan bahwa prestasi belajar merupakan taraf 
keberhasilan siswa dalam mempelajari materi pelajaran di sekolah dinyatakan dalam bentuk skor yang diperoleh dari hasil tes mengenai sejumlah materi pelajaran tertentu.

Dari pengertian di atas dapat disimpulkan prestasi belajar adalah tingkat penguasaan siswa terhadap suatu mata pelajaran, baik berupa pengetahuan maupun ketrampilan, yang dinyatakan dengan simbol-simbol atau angka setelah mengikuti program pengajaran dalam waktu tertentu.

\section{Faktor-faktor yang Mempengaruhi Prestasi Belajar}

Ada banyak pendapat mengenai faktor-faktor yang dapat mempengaruhi prestasi belajar siswa.

Nana Syaodih Sukmadinata (2003: 162) mengemukakan dua faktor yang mempengaruhi prestasi belajar, yaitu:

1. Faktor-faktor dari dalam individu.

a) Aspek jasmani; b) Aspek psikis atau rohaniah; c) Kondisi intelektual; d) Kondisi sosial; e) Situasi afektif, belajar perlu didukung oleh motivasi yang kuat dan konstan.

2. Ketrampilan yang dimiliki oleh individu yang bersangkutan,

3. Faktor-faktor di luar individu.

a. Keluarga.

b. Lingkungan sekolah.

Sedangkan menurut Ngalim Purwanto (2003: 107), faktor-faktor yang dapat mempengaruhi proses dan hasil belajar adalah:

1. Faktor luar, meliputi :

a. Lingkungan

b. Instrumental.

2. Faktor dalam, meliputi :

a. Fisiologis.

b. Psikologis.

Berdasarkan beberapa pendapat di atas, maka dapat disimpulkan bahwa faktor-faktor yang mempengaruhi prestasi belajar adalah sebagai berikut:

1. Faktor yang berasal dari dalam individu. Faktor ini meliputi inteligensi, kondisi fisik, kondisi psikis, minat, tanggapan, ingatan, fantasi, perhatian, sikap, bakat, dan motivasi. 
2. Faktor yang berasal dari luar individu. Faktor ini meliputi:
a. Faktor keluarga.
b. Faktor lingkungan.
c. Faktor sekolah.
d. Faktor masyarakat.

\section{Kemandirian Belajar}

\section{Pengertian Kemandirian Belajar}

Kemandirian adalah hal atau keadaan dapat berdiri sendiri tanpa bergantung pada orang lain (Kamus Besar Bahasa Indonesia 2007: 710). Hasan Basri (1996: 53) mengemukakan kemandirian dalam arti psikologis dan mentalis, keadaan seseorang dalam kehidupannya yang mampu memutuskan atau mengerjakan sesuatu tanpa bantuan orang lain.

Dari pendapat di atas dapat disimpulkan bahwa kemandirian belajar adalah kemauan belajar sendiri tanpa ketergantungan atau pengaruh orang lain, kemampuan diri sendiri dalam menyelesaikan masalah belajar.

\section{Ciri-ciri Kemandirian Belajar}

Untuk mengetahui apakah seseorang itu mempunyai kemandirian belajar, maka perlu diketahui ciri-ciri kemandirian belajarnya.

Menurut Sardiman (2007: 45) ciri-ciri kemandirian belajar adalah sebagai berikut:

1. Adanya kecenderungan untuk berpendapat, berperilaku dan bertindak atas kehendak sendiri.

2. Memiliki keinginan yang kuat untuk mencapai suatu tujuan.

3. Membuat perencanaan dan berusaha dengan ulet dan tekun untuk mewujudkan harapan.

4. Mampu untuk berfikir dan bertindak secara kreatif, penuh inisiatif dan tidak sekedar meniru.

5. Memiliki kecenderungan untuk mencapai kemampuan yaitu: untuk meningkatkan prestasi belajar.

6. Mampu menemukan sendiri tentang sesuatu yang harus dilakukannya tanpa mengharapkan bimbingan dengan pengarahan orang lain. 
Dari pendapat di atas dapat disimpulkan ciri-ciri kemandirian belajar adalah adanya niat yang kuat dari dalam dirinya untuk belajar, adanya keinginan untuk maju dan berpikir kritis, belajar dengan inisiatif sendiri tanpa adanya paksaan dari orang lain, mempunyai rasa percaya diri yang kuat, mempunyai perencanaan dan ulet serta tekun dalam belajar.

\section{Perhatian Orang Tua}

Menurut Sumadi Suryabrata (2002: 14) perhatian diartikan sebagai banyak sedikitnya kesadaran yang menyertai aktivitas yang sedang dilakukan. Bimo Walgito (1988: 56) mendefinisikan perhatian merupakan pemusatan atau konsentrasi dari seluruh aktivitas individu yang ditujukan kepada sesuatu atau sekumpulan objek.

Menurut Soelaeman (1994: 179) "istilah orang tua hendaknya tidak diartikan sebagai orang yang dituakan dan karenanya diberi tanggung jawab untuk merawat dan mendidik anak menjadi manusia dewasa". Istilah orang tua memberikan tekanan perhatian kepada nasehatnya yang khusus dengan anaknya, sehingga langsung mengacu kepada peranan, tugas dan tanggung jawabnya sebagai orang tua.

Dari penjelasan di atas dapat disimpulkan bahwa perhatian orang tua adalah pemusatan kesadaran dari seluruh aktivitas ayah dan ibu yang ditujukan kepada anakanaknya secara serius, bertanggungjawab, dan adanya usaha kewaspadaan.

Menurut Syamsu Yusuf (2001: 48) terdapat beberapa pola sikap atau perlakuan orang tua terhadap anak yaitu:

1. Terlalu melindungi.

2. Pembolehan.

3. Penolakan.

4. Penerimaan.

5. Dominasi.

6. Penyerahan.

7. Terlalu disiplin.

Di samping menampilkan sikap-sikap yang baik dalam menghadapi anak yang sedang belajar, orang tua hendaknya dapat berpartisipasi langsung dalam meningkatkan motivasi anaknya dalam belajar dengan cara memberikan penguatan dan penghargaan terhadap usaha belajar anak yang baik.

Dapat disimpulkan bahwa perhatian orang tua kepada anak-anak dalam hal belajar dapat diwujudkan melalui empat cara, yaitu memberikan kebebasan, memberikan 
penghargaan dan hukuman, pemberian contoh atau teladan, dan membantu kesulitannya.

\section{Metode Penelitian}

Jenis penelitian ini adalah ex post facto, desain penelitiannya adalah korelasi. Penelitian ini bersifat kuantitatif karena dimaksudkan untuk mengetahui hubungan kemandirian belajar dan perhatian orang tua dengan prestasi belajar siswa kelas $X$ Administrasi Perkantoran SMK Kristen 2 Klaten.

Dalam penelitian ini terdapat tiga variabel yang berkaitan dengan permasalahan yang terjadi di lapangan yaitu kemandirian belajar (X1) sebagai variabel bebas, perhatian orang tua (X2) sebagai variabel bebas dan prestasi belajar (Y) sebagai variabel terikat.

Populasi dalam penelitian ini adalah 50 siswa kelas $X$ Administrasi Perkantoran. Teknik pengumpulan data yang digunakan dalam penelitian ini adalah:

1. Angket

2. Dokumentasi

Instrumen dalam hal ini berupa angket tertutup yaitu angket yang disajikan dengan empat alternatif jawaban sehingga responden tinggal memberi tanda centang $(\sqrt{ })$ pada kolom jawaban yang telah tersedia. Langkah-langkah penyusunan instrumen adalah sebagai berikut:

1. Membuat kisi-kisi.

2. Menyusun butir-butir pernyataan.

3. Penetapan Skor.

\section{Pembahasan}

\section{Hubungan Kemandirian Belajar dengan Prestasi Belajar.}

Hasil penelitian menunjukkan bahwa variabel kemandirian belajar terdapat hubungan positif dan signifikan dengan prestasi belajar. Hal tersebut ditunjukkan dengan koefisien korelasi $r_{x 1 y}$ sebesar 0,492 .

Berdasarkan data variabel kemandirian belajar yang diolah dengan program SPSS versi 16 diperoleh skor tertinggi sebesar 50 dan skor terendah sebesar 15. Adapun nilai rerata (mean) sebesar 25,58, median sebesar 26, modus sebesar 26 dan standar deviasi 6,77 . 
Kemandirian seperti halnya kondisi psikologis yang lain, dapat berkembang dengan baik jika diberi kesempatan untuk berkembang melalui latihan secara terus menerus dan dilakukan sejak dini. Latihan tersebut dapat berupa pemberian tugastugas tanpa bantuan. Tugas-tugas tersebut disesuaikan dengan usia dan kemampuan siswa.

Kemandirian belajar ditunjukkan dengan adanya kemauan siswa untuk mencari sumber-sumber belajar, misalnya pergi ke perpustakaan yang memberikan pelayanan untuk memperoleh buku-buku pelajaran atau bahan-bahan belajar melalui media lain serta tugas-tugas yang diberikan oleh guru tanpa adanya ketergantungan dari orang lain.

Dengan adanya hubungan yang positif dan signifikan antara kemandirian belajar dengan prestasi belajar menerapkan prinsip-prinsip kerjasama dengan kolega dan pelanggan, yang ditunjukkan dengan koefisien korelasi sebesar 0,492 dan $r_{\text {tabel }}$ 0,279 dengan taraf signifikansi $5 \%$, hal ini berarti terdapat hubungan positif dan signifikan antara kemandirian belajar dengan prestasi belajar dalam penelitian ini mendukung pendapat yang dikemukakan di atas.

\section{Hubungan Perhatian Orang Tua dengan Prestasi Belajar.}

Hasil kedua dari penelitian ini adalah terdapat hubungan positif dan signifikan antara perhatian orang tua dengan prestasi belajar yang ditunjukkan dengan koefisien korelasi $r_{x 2 y}$ sebesar 0,737 .

Berdasarkan data variabel perhatian orang tua yang diolah menggunakan program SPSS versi 16 diperoleh skor tertinggi 75 dan skor terendah 21. Hasil analisis menunjukkan harga rerata (mean) sebesar 37,16 , median sebesar 32 , modus sebesar 27 dan standar deviasi sebesar 12,44.

Berikut adalah tabel distribusi frekuensi variabel perhatian orang tua.

\begin{tabular}{|c|c|c|c|c|c|}
\hline No & Interval & Frekuensi & $\begin{array}{c}\text { Frekuensi } \\
\text { Kumulatif }\end{array}$ & $\begin{array}{c}\text { Frekuensi } \\
\text { Relatif (\%) }\end{array}$ & $\begin{array}{c}\text { Frekuensi Kumulatif } \\
(\%)\end{array}$ \\
\hline 1 & $21-28,71$ & 15 & 50 & 30 & 30 \\
\hline 2 & $28,71-36,42$ & 14 & 35 & 28 & 58 \\
\hline 3 & $36,42-44,13$ & 7 & 21 & 14 & 72 \\
\hline 4 & $44,13-51,84$ & 6 & 14 & 12 & 84 \\
\hline 5 & $51,84-59,55$ & 7 & 8 & 14 & 98 \\
\hline 6 & $59,55-67,26$ & 0 & 1 & 0 & 100 \\
\hline 7 & $67,26-75$ & 1 & 1 & 2 & 98 \\
\hline \multicolumn{2}{|c|}{ Jumlah } & 50 & & $100 \%$ & \\
\hline
\end{tabular}


Berdasarkan tabel distribusi frekuensi variabel perhatian orang tua di atas pada interval 36,42-44,13 dan interval 51,84-59,55 berjumlah 7 siswa (14\%). Pada interval 21-28,71 berjumlah 15 siswa (30\%), sedangkan interval 28,71-36,42 sebanyak 14 siswa (28\%), interval 44,13-51,84 sebanyak 6 siswa (12\%), interval 59,55-75 sebanyak 1 siswa $(2 \%)$.

Dapat diidentifikasi kecenderungan skor variabel perhatian orang tua yang dikategorikan menjadi tiga yaitu tinggi, sedang dan rendah yaitu sebagai berikut:

\begin{tabular}{|c|c|c|c|c|c|}
\hline No. & Skor & Frekuensi & $\begin{array}{c}\text { Frekuensi } \\
\text { Relatif }(\%)\end{array}$ & $\begin{array}{c}\text { Frekuensi } \\
\text { Kumulatif (\%) }\end{array}$ & Kategori $^{\text {Kand }}$ \\
\hline 1 & $<24,72$ & 6 & 12 & 12 & Rendah \\
\hline 2 & $24,72-49,60$ & 35 & 70 & 82 & Sedang \\
\hline 3 & $>49,60$ & 9 & 18 & 100 & Tinggi \\
\hline
\end{tabular}

Tabel di atas menunjukkan bahwa terdapat $9(18 \%)$ responden yang berada dalam kategori tinggi, $35(70 \%)$ responden berada dalam kategori sedang, $6(12 \%)$ responden masuk dalam kategori rendah.

Perhatian orang tua yang tinggi merupakan salah satu faktor penentu prestasi belajar siswa, hal ini sejalan dengan pendapat Wasty Soemanto (2008: 95) orang tua adalah peletak dasar bagi perkembangan pribadi anak di masa-masa selanjutnya. Orang tua ingin agar anak-anaknya mencapai prestasi yang tinggi di sekolah. Mereka ingin membantu perkembangan intelektual dan sosial anak, tetapi orang tua memiliki kesukaran untuk mewujudkan keinginan agar anak berprestasi seperti yang diharapkan.

Dengan adanya hubungan yang positif dan signifikan antara perhatian orang tua dengan prestasi belajar yang ditunjukkan dengan koefisien korelasi sebesar (R) 0,737 $r_{\text {tabel }} 0,279$ dengan taraf signifikansi $5 \%$ dalam penelitian ini mendukung pendapat yang dikemukakan di atas.

3. Hubungan antara Kemandirian Belajar dan Perhatian Orang Tua secara Bersamasama dengan Prestasi Belajar.

Hasil ketiga dari penelitian ini adalah terdapat hubungan positif dan signifikan antara kemandirian belajar dan perhatian orang tua dengan prestasi belajar yang ditunjukkan dengan koefisien korelasi $(R)$ sebesar 0,742 dan nilai $F_{\text {hitung }} 28,779>F_{\text {tabel }}$ sebesar 3,18.

Berdasarkan data variabel prestasi belajar yang diolah dengan program SPSS versi 16 diperoleh skor tertinggi sebesar 92 dan skor terendah sebesar 69. Adapun harga rerata (mean) sebesar 79,52 , median sebesar 79 , modus sebesar 72 dan standar deviasi 6,68. 
Berikut adalah tabel distribusi frekuensi variabel prestasi belajar.

\begin{tabular}{|c|c|c|c|c|c|}
\hline No. & Interval & Frekuensi & $\begin{array}{c}\text { Frekuensi } \\
\text { Kumulatif }\end{array}$ & $\begin{array}{c}\text { Frekuensi } \\
\text { Relatif (\%) }\end{array}$ & $\begin{array}{c}\text { Frekuensi } \\
\text { Kumulatif (\%) }\end{array}$ \\
\hline 1 & $69-72,29$ & 8 & 50 & 16 & 100 \\
\hline 2 & $72,29-75,58$ & 10 & 42 & 20 & 84 \\
\hline 3 & $75,58-78,87$ & 5 & 32 & 10 & 64 \\
\hline 4 & $78,87-82,16$ & 7 & 27 & 14 & 54 \\
\hline 5 & $82,16-85,45$ & 9 & 20 & 18 & 40 \\
\hline 6 & $85,45-88,74$ & 6 & 11 & 12 & 22 \\
\hline 7 & $88,74-92$ & 5 & 5 & 10 & 10 \\
\hline \multicolumn{7}{|c|}{ Jumlah } & 50 & & $100 \%$ & \\
\hline
\end{tabular}

Berdasarkan tabel distribusi frekuensi variabel prestasi belajar di atas pada interval 88,74 dan interval 75,58-78,87 berjumlah 5 siswa (10\%). Pada interval 69-72,29 berjumlah 8 siswa (16\%), sedangkan interval $72,29-75,58$ sebanyak 10 siswa $(20 \%)$, interval 75,58-78,87 sebanyak 7 siswa (14\%), interval $82,16-85,45$ sebanyak 9 siswa $(18 \%)$, sedangkan interval $85,45-88,74$ sebanyak 6 siswa $(12 \%)$.

Dapat diidentifikasi kecenderungan skor variabel prestasi belajar yang dikategorikan menjadi tiga yaitu tinggi, sedang dan rendah yaitu sebagai berikut:

\begin{tabular}{|c|c|c|c|c|c|}
\hline No. & Skor & Frekuensi & $\begin{array}{c}\text { Frekuensi } \\
\text { Relatif }(\%)\end{array}$ & $\begin{array}{c}\text { Frekuensi } \\
\text { Kumulatif }(\%)\end{array}$ & Kategori \\
\hline 1 & $<72,84$ & 8 & 16 & 16 & Rendah \\
\hline 2 & $72,84-86,20$ & 33 & 66 & 82 & Sedang \\
\hline 3 & $>86,20$ & 9 & 18 & 100 & Tinggi \\
\hline
\end{tabular}

Tabel di atas menunjukkan bahwa terdapat $9(18 \%)$ responden yang berada dalam kategori tinggi, $33(66 \%)$ responden berada dalam kategori sedang, $8(16 \%)$ responden masuk dalam kategori rendah.

W.S Winkel (1996: 97) menjelaskan bahwa prestasi belajar merupakan suatu kemampuan internal yang telah menjadi milik pribadi seseorang dan memungkinkan orang itu melakukan sesuatu atau memberikan hasil tertentu. Prestasi belajar dipengaruhi oleh banyak faktor, baik internal maupun eksternal. Jika kedua faktor tersebut dimaksimalkan fungsinya maka akan membawa pengaruh yang baik pada prestasi belajar. 
Siswa yang memiliki sikap mandiri akan belajar dengan serius dan mengerjakan tugas dengan penuh ketekunan sampai benar-benar menguasai pelajaran tersebut. Melalui sikap mandiri yang dimiliki siswa, diharapkan proses belajar mengajar akan berjalan dengan lancar dan akan memperoleh hasil belajar yang maksimal.

Anak yang mendapat perhatian dari orang tua akan lebih termotivasi untuk belajar lebih giat, sehingga kegiatan belajar anak mengalami peningkatan dan dengan adanya peningkatan belajar maka prestasi belajar siswa akan semakin meningkat.

Kemandirian belajar dan perhatian orang tua yang tinggi dapat membuat prestasi belajar siswa menjadi tinggi. Siswa yang kemandirian belajar tinggi tidak akan bergantung pada teman sebaya dalam belajar atau dalam mengerjakan tugas-tugas sekolah.

Ketika dilakukan analisis bersama-sama dan antar kedua variabel bebas dengan satu variabel terikat diperoleh hubungan yang positif dan signifikan antara kemandirian belajar dan perhatian orang tua dengan prestasi belajar belajar. Hal tersebut ditunjukkan dengan koefisien korelasi $(R)$ sebesar 0,742 , koefisien determinan $R^{2}$ sebesar 0,550 dan nilai $F_{\text {hitung }} 28,779$ lebih besar dari $F_{\text {tabel }} 3,18$ pada taraf signifikansi $5 \%$.

Berdasarkan hasil analisis korelasi ganda yang dilakukan dalam penelitian ini diperoleh koefisien determinasi yang menunjukkan bahwa varians prestasi belajar dapat dijelaskan oleh kombinasi dari kedua variabel bebas. Jika korelasi berada di antara 0,400-0,599 maka korelasinya termasuk dalam kategori sedang.

\section{Kesimpulan dan Implikasi}

\section{Kesimpulan}

1. Kemandirian belajar memiliki hubungan positif dan signifikan dengan prestasi belajar, dengan koefisien korelasi ( $r$ ) sebesar 0,492 ( $\left.r_{x 1 y}>r_{t} 5 \%\right)$.

2. Perhatian orang tua memiliki hubungan positif dan signifikan dengan prestasi belajar, dengan koefisien korelasi $(r)$ sebesar $0,737\left(r_{x 2 y}>r_{t} 5 \%\right)$.

3. Terdapat hubungan positif dan signifikan kemandirian belajar dan perhatian orang tua secara bersama-sama dengan prestasi belajar, yang ditunjukkan dengan koefisien korelasi (R) 0,742, koefisien determinasi (R2) 0,550 dan $F_{\text {hitung }} 28,779$ ( $F_{\text {hitung }} 28,779>$ $F_{\text {tabel }} 3,18$ dengan taraf signifikansi $5 \%$ ).

\section{Implikasi}

1. Terdapat hubungan positif dan signifikan kemandirian belajar dengan prestasi belajar, memberikan petunjuk bahwa dengan adanya kemandirian belajar dalam diri siswa maka dapat meningkatkan prestasi belajar. Siswa yang mempunyai kemauan sendiri 
untuk belajar, inisiatif sendiri untuk belajar, percaya diri dan tidak bergantung pada orang lain dapat lebih meningkatkan prestasi belajarnya.

2. Terdapat hubungan positif dan signifikan perhatian orang tua dengan prestasi belajar, memberikan petunjuk bahwa dengan perhatian orang tua yang tinggi dapat mendorong siswa untuk mendapatkan prestasi belajar yang tinggi. Siswa yang diperhatikan oleh orang tua akan memiliki motivasi belajar yang tinggi sehingga menunjukkan semangat belajar dan memiliki keinginan untuk selalu meningkatkan hasil belajarnya.

3. Terdapat hubungan positif dan signifikan kemandirian belajar dan perhatian orang tua secara bersama-sama dengan prestasi belajar. Kesimpulan ini dapat dijadikan bahan pertimbangan bagi sekolah untuk mengambil kebijakan dalam meningkatkan prestasi belajar dengan mempertimbangkan faktor-faktor kemandirian belajar dan perhatian orang tua.

\section{Daftar Pustaka}

Bimo Walgito. 1988. Pengantar Psikologi Umum. Yogyakarta: Andi Offset.

Hasan Basri. 1996. Remaja Berkualitas Problematika Remaja dan Solusinya. Yogyakarta: Pustaka Pelajar.

http://peringkat-pendidikan-indonesia-turun.html, diunduh 7 Februari 2012

Muhibbin Syah. 2006. Psikologi Pendidikan. Bandung: Rosdakarya.

Nana Syaodih Sukmadinata. 2003. Landasan Psikologi Proses Pendidikan. Bandung: PT Remaja Rosdakarya.

Ngalim Purwanto. 2003. Psikologi Pendidikan. Bandung: Remaja Rosdakarya.

Sardiman, AM. 2007. Interaksi dan Motivasi Belajar Mengajar. Jakarta: PT Raja Grafindo Persada.

Soelaeman. 1994. Pendidikan dalam Keluarga. Bandung: CV Alfabeta.

Sumadi Suryabrata. 2002. Psikologi Pendidikan. Jakarta: Rajagrafindo.

Syamsu Yusuf. 2001. Psikologi Perkembangan Anak \& Remaja. Bandung: Rosdakarya.

Tim. 2007. Kamus Besar Bahasa Indonesia. Jakarta: Balai Pustaka.

Wasty Soemanto. 2008. Sekuncup Ide Operasional Pendidikan Kewiraswastaan. Jakarta: Bumi Aksara.

Winkel W. S. 1996. Psikologi Pengajaran. Jakarta: Grasindo. 